\title{
Khatkar Kalan SPV Electricity Generating System: A Case Study
}

\author{
A. F. Sherwani \\ Department of Mechanical Engineering, Faculty of Engineering and Technology, Jamia Millia Islamia, New Delhi, 110025
}

\begin{abstract}
Solar photovoltaic systems are prohibitively expensive in terms of installation costs. Power from them is intermittent and available if solar radiations are available. On the other hand, PV electricity systems are free from ever-rising costs of conventional fuel. They also incur very less operation and maintenance costs. Using solar-PV power, it looks uneconomical in the short term, but may be profitable in the long term. It is therefore, interesting to identify the factors that can make investment in solar PV power generation is to be acceptable. In this paper life cycle analysis for $200 \mathrm{kWp}$ solar photovoltaic electricity generation system has been carried out. It identifies the factors that can make the investment in a solar PV plant more favourable than investment in other conventional electricity generation sources. The energy payback time and the normalized greenhouse gas (GHG) emissions has been evaluated and found to be 4.73 years and $143.86 g-\mathrm{CO}_{2 e q} / \mathrm{kWh}$ respectively.
\end{abstract}

Keywords: Energy payback time, GHG emissions, India, Life Cycle assessment, SPV.

\section{Introduction}

Life cycle assessment study is also called as cradle to grave study of the system/ product. It is used to calculate the energy consumption in manufacturing, installation and transportation of SPV systems. LCA studies also aims in comparing and analysis of the environmental impacts of products and services [1, 2]. The EPBT (energy pay-back time) period is used as an indicator to show the amount of energy consumed. EPBT is the time required for the system to generate the equivalent amount of energy which is consumed in the construction, operation, maintenance and decommissioning of the energy generating system. It indicates number of years required to recover the energy consumed in the installation of the plant through energy (electricity) generation by the plant. The total energy requirement of the electricity generating projects and the annual power generated are concerned with the primary energy. To convert the annual power generation $\left(\mathrm{kWh}_{\mathrm{e}}\right)$ to primary energy, the average efficiency of the electricity generation projects in the studied country is needed. For the present study best average efficiency of electricity generation for India is considered as 0.40. Estimation of EPBT is given as:

$$
E P B T(\text { years })=\frac{\text { Total primaryenergy requirement of system throughout its life cycle }(G J)}{\text { Annual primaryenergy generation by the system }(G J / \text { year })}
$$

The total life-cycle GHG emissions $\left(\mathrm{Mg}-\mathrm{CO}_{2 \mathrm{eq}}\right)$ were generally estimated according to the full operational life cycle of each system from the commissioning of the plant to its full operation (cradle to grave). These emissions are found to vary widely within each technology. For the estimation of GHG emissions for the present study, life time of the projects is considered to be 20 years. Estimation of GHG emissions is given as:

$$
G H G \text { emissions }=\frac{\text { Total } \mathrm{CO}_{2} \text { emissions throughout its life cycle }\left(g-\mathrm{CO}_{2 e q}\right)}{\text { Annual power generation }\left(k W h_{e} / \text { year }\right) \times \operatorname{lifetime}(\text { year })}
$$

\begin{abstract}
Numerous LCA studies have been carried out for SPV systems and a wide range of results in EPBT have been found. Various studies on GHG emission estimation for SPV systems have also been carried out and also a wide range of results have been found [2-6].
\end{abstract}

SPV system design is very dependent on the geographical location of the system, since the amount of electricity generated varies with the irradiance and temperature.
Under the demonstration of grid interactive solar photovoltaic program, a $200 \mathrm{kWp}$ capacity, grid interactive power plant has been installed at village Khatkar Kalan district Nawanshahr (Punjab) with the help of MNES (Ministry of Non-conventional Energy Sources), IREDA (Indian Renewable Energy Development Agency Limited) and state government of Punjab under world bank credit of line. The village Khatkar Kalan is a small village comprising around 300 households. Due to its historical importance, it has been provided electricity along with four other villages. However, due to the increasing load demand, grid voltage 


\section{International Journal of Science and Research (IJSR) \\ ISSN (Online): 2319-7064 \\ Index Copernicus Value (2013): 6.14 | Impact Factor (2014): 5.611}

drops along the line during peak demand which causes the transformer to overheat. The village load consists of mainly lighting and water pumping which has a daily average value of about $140 \mathrm{kVA}$. As good grid availability is there from the nearby lines, it would be ideal to establish a SPV grid interaction power plant in parallel with the grids so that the conditions of providing supports to the grids as well as 1-2 hours backup for emergencies are met during blackout periods. During periods of non utilization, the power generation can be exported to the grids. For the present study

\section{Description of System}

The system is designed to provide maximum export of solar power of the grid and to provide 2 hours autonomy in case of grid outage. The nominal capacity of the project is 201.6 $\mathrm{kWp}$ based on 70Wp PV module. SPV module shall be stand voltage up to $2 \mathrm{KV}$ DC between the earthen frame and shorted line terminals. The overall dimensions of PV module is $1208( \pm 3) \times 528( \pm 2) \times 38( \pm 1) \mathrm{mm}^{3}$. Module is single glass laminated type 36 cells $(9 \times 4)$ in series and having $8.0 \mathrm{~kg}$ weight. The SPV module consists of mono crystalline silicon cell which is having an efficiency of $13 \%$. The total area required for installation of array is approximately 3000 $\mathrm{m}^{2}$ which was available at selected site. 20 module of $70 \mathrm{Wp}$ each connected in series will form a series string and 144 such string will be connected in parallel. Each array output of MTB is terminated onto PJB (panel junction box). As the entire generation data was not available for the complete year. Based upon average monthly data, electricity generation for a year has been estimated. The average approximate yearly electricity generated by the system is $312350 \mathrm{kWh}_{\mathrm{e}}$. A list of components and materials used and the site details of the present SPV system has been given in Table $1 \&$ Table 2 respectively.

\section{Material Inventory}

Numerous studies have been carried out to estimate the energy consumption in the manufacturing of monocrystalline solar PV modules [7, 1]. Hence for energy consumption for mono-crystalline SPV modules has been taken from the above mention study. The energy consumption for module is considered $16 \mathrm{MWh}_{\mathrm{t}} / \mathrm{kW}_{\mathrm{p}}$. The mono-crystalline PV cell having an efficiency of $17 \%$ is considered. In the present study, $10 \%$ of the module weight is considered to be the weight of the frame. Frame has been made up of aluminum. There are few available data about energy requirements for change regulators and inverter manufacturing, especially for small and medium size facilities. Sherwani et al. [11] estimated a $0.5 \mathrm{MWH}$ for energy requirements. No significant material inflow is involved during operation and decommissioning phases.

\section{Life Cycle Input Energy}

The weight and embodied of different components of SPV system are shown in Table 3. To convert primary energy into its equivalent electrical energy, a best average efficiency is considered to be $40 \%$. For the estimation of concrete structures, the studies of Reddy \& Jagadish [8] and Shukla et al. [9] are used which has been carried out for India. The energy adopted for inverter and aluminium is based on its energy consumption presented by GEMIS [10]. The distance by road between Khatkar kalan and Bharat Heavy Electrical Limited (Hyderabad) is approximately $2000 \mathrm{~km}$. The primary energy value is considered as 0.41 $\mathrm{MJ} /$ Ton-km for transportation purpose.

\section{Life Cycle GHG Emissions}

GHG emissions are normally occurs during manufacturing, installation and transportation phases of solar PV modules. Among all the electricity generation sources, the coal has highest value of GHG emissions while nuclear based electricity generation has the maximum value. The GHG emissions of different components of SPV system are shown in Table 4. In this study, GHG emission is evaluated throughout 20 years lifetime of SPV system. Among the renewable energy based electricity generation, wind has the highest potential and then there is a potential for small hydropower. An average value of GHG emission factor for the entire electricity generation sector has been taken from Sherwani et al. [11]. As wind and small hydro have the lesser value than the 35 and in the electricity generation.

Table 1: Technical specification of the PV plant

\begin{tabular}{|c|c|c|c|c|}
\hline S. No. & Component & Specification & Material & Numbers \\
\hline 1 & PV Module & $1208( \pm 3) \times 528( \pm 2) \times 38( \pm 1)$ & Anodised aluminium & 2880 \\
\hline 2 & PV Cell & $1: 100, \mathrm{~b}: 55$ & Mono-crystalline silicon & 103680 \\
\hline 3 & Array junction box & $1: 4000, \mathrm{~h}: 300, \mathrm{t}: 100$ & Copper & 96 \\
\hline 4 & Main junction box & $1: 4000, \mathrm{~h}: 300, \mathrm{t}: 100$ & Copper & 6 \\
\hline 5 & Sub main junction box & $1: 4000, \mathrm{~h}: 300, \mathrm{t}: 100$ & Copper & 28 \\
\hline 6 & Control room and battery & $1: 6040, \mathrm{~b}: 4530, \mathrm{~h}: 4433$ & Steel, Bricks, Cement & 1 \\
\hline 7 & Battery & $1: 500, \mathrm{~b}: 212, \mathrm{~h}: 256$ & Plastic, Rubber, Lead & 120 \\
\hline 8 & Power wire & $\mathrm{d}: 6, \mathrm{l}: 3800$ & Copper & 95 \\
\hline 9 & Structural column & $\mathrm{d}: 76.5, \mathrm{~h}: 1900, \mathrm{t}: 30$ & Steel & 324 \\
\hline 10 & Wire & $1: 6435$ & Copper & 150 \\
\hline 11 & Inverter & $1: 1500, \mathrm{~b}: 1290, \mathrm{~h}: 1410$ & Mix material & 3 \\
\hline
\end{tabular}

$\mathrm{l}=$ length, $\mathrm{b}=$ breadth, $\mathrm{t}=$ thickness, $\mathrm{h}=$ height and $\mathrm{d}=$ diameter; All dimensions are in $\mathrm{mm}$. 


\section{International Journal of Science and Research (IJSR) \\ ISSN (Online): 2319-7064}

Index Copernicus Value (2013): 6.14 | Impact Factor (2014): 5.611

Table 2: Location and Site details of Solar PV system

\begin{tabular}{|c|c|}
\hline Location & Punjab \\
\hline Land ownership & $\begin{array}{c}\text { Owned by local Panchayat (A local } \\
\text { governing body) }\end{array}$ \\
\hline Ambient Temperature & $4-45^{\circ} \mathrm{C}$ \\
\hline Latitude & $31.42^{\circ} \mathrm{N}$ \\
\hline Longitude & $75.58^{\circ} \mathrm{E}$ \\
\hline Elevation & $238 \mathrm{~m}$ above mean sea level \\
\hline Tilt angle & $30^{\circ}$ (fixed) \\
\hline
\end{tabular}

Table 3: Component Wise Distribution of Embodied Energy for PV system

\begin{tabular}{|c|c|c|c|c|}
\hline $\begin{array}{l}\text { S. } \\
\text { No. }\end{array}$ & Component & Material & $\begin{array}{l}\text { Weight } \\
(\mathrm{kg})\end{array}$ & $\begin{array}{c}\text { Embodied } \\
\text { Energy } \\
\left(k W h_{e}\right) \\
\end{array}$ \\
\hline 1 & PV module & Mono-crystalline & - & 1290240.00 \\
\hline 2 & Frame & Aluminum & 907.2 & 99447.95 \\
\hline 3 & Support structure & Steel & 1611.95 & 9465.48 \\
\hline 4 & Power wire & Copper & 12.04 & 361.92 \\
\hline 5 & Array junction box & Copper & 66 & 2018.84 \\
\hline 6 & Main junction box & Copper & 5 & 183.06 \\
\hline 7 & $\begin{array}{l}\text { Sub main junction } \\
\text { box }\end{array}$ & Copper & 22 & 550.59 \\
\hline 8 & Wire & Copper & 125 & 3054.71 \\
\hline 9 & Building & $\begin{array}{c}\text { Mix material } \\
\text { (Steel, Brick, } \\
\text { Cement, Sand, } \\
\text { Other) }\end{array}$ & 81145.96 & 32250.44 \\
\hline 10 & Pavement & Brick & 157 & 9344.88 \\
\hline 11 & Grounding & $\begin{array}{l}\text { Plastic, Rubber, } \\
\text { Other }\end{array}$ & 124.8 & 3229.80 \\
\hline 12 & Inverter & Mix Material & - & 7000 \\
\hline 13 & Transportation & - & - & 20986.12 \\
\hline \multicolumn{4}{|c|}{ Total } & 1478133.79 \\
\hline
\end{tabular}

Table 4: Component wise GHG emission of SPV system

\begin{tabular}{|c|c|c|c|}
\hline $\begin{array}{c}S . \\
\text { No. }\end{array}$ & Component & $\begin{array}{c}\text { GHG } \\
\text { Emissions }(k g- \\
\left.\text { CO }_{2}\right)\end{array}$ & $\begin{array}{c}\text { Percentage GHG } \\
\text { Emissions }\end{array}$ \\
\hline 1 & PV module & 784465.92 & $87.29 \%$ \\
\hline 2 & Frame & 60464.3536 & $6.73 \%$ \\
\hline 3 & Support structure & 5755.01184 & $0.64 \%$ \\
\hline 4 & Power wire & 220.04736 & $0.02 \%$ \\
\hline 5 & Array junction box & 1227.45472 & $0.14 \%$ \\
\hline 6 & Main junction box & 111.30048 & $0.01 \%$ \\
\hline 7 & Sub main junction box & 334.75872 & $0.04 \%$ \\
\hline 8 & Wire & 1857.26368 & $0.21 \%$ \\
\hline 9 & Building & 19608.26752 & $2.18 \%$ \\
\hline 10 & Pavement & 5681.68704 & $0.63 \%$ \\
\hline 11 & Grounding & 1963.7184 & $0.22 \%$ \\
\hline 12 & Inverter & 4256 & $0.47 \%$ \\
\hline 13 & Transportation & 12759.56096 & $1.42 \%$ \\
\hline & Total & $\mathbf{8 9 8 7 0 5 . 3 4 4 3}$ & $\mathbf{1 0 0 \%}$ \\
\hline
\end{tabular}

\section{Results}

The total primary energy requirement for the Khatkar Kalan solar PV electricity generation system is $1478133.79 \mathrm{kWh}_{\mathrm{e}}$. The EPBT is calculated and it comes to be 4.73 years which is very less if we compare this value with the other studies related to PV based electricity generation system. As the mono-crystalline solar cells are very less energy intensive elements as compared to others but their conversion efficiency is also very less as compared to others solar cells.
The total GHG emissions for Khatkar Kalan SPV system is $898705.3443 \mathrm{~kg}-\mathrm{CO}_{2}$. The life time of this system is considered to be 20 years. The GHG emission for $1 \mathrm{kWh}_{\mathrm{el}}$ is calculated as $143.86 \mathrm{~kg}-\mathrm{CO}_{2} / \mathrm{kWh}_{\mathrm{el}}$.

\section{Conclusions of Case Study}

LCA study has been performed for Khatkar Kalan SPV electricity generation system. The generation of electricity by using SPV is environmentally friendly as compared to fossil fuel based energy generation sources. It has been observed that highest energy consumption \& GHG emissions are in manufacturing/fabrication of PV modules. The initial cost of installing this type of system is high and having less efficiency. A good amount of work has already been going on in this area which will lead to more improvement and cost reducing in these systems which further reduce the cost of electricity generation.

\section{References}

[1] Kannan, R. Leong, K.C, Osman, R. Ho. H.K. Tso, C.P. (2005). "Life Cycle assessment study of solar PV systems: An example of a $2.7 \mathrm{~kW}_{\mathrm{p}}$ distributed solar PV system Singapore", Solar energy. (68)

[2] Niewlaar, E. Alsema, E. Van, Engelenburg B. Usinf. (1996). "Life cycle assessments for the environmental evaluation of greenhouse gas mitigation options". Energy Conversion and Management;37:831-6. (69)

[3] Alsema, E. A. (2000). "Energy pay back time and $\mathrm{CO}_{2}$ emissions of PV system", Progress in Photovoltaic Research and Application;8:17-25. (70)

[4] Pacca, S, Sivaraman, D. Keoleain, G. A. (2007). "Parameters affecting the life cycle performance of PV technologies and systems", Energy Policy;35:3316-26. (71)

[5] Ito, M. Kato, K. Komoto, K. Kichimi, T. Kurokava, K. (2008). "A comparative study on cost and life cycle analysis for $100 \mathrm{MW}$ very large-scale (VLS-PV) systems in deserts using m-si, a-si CdTe and CIS modules", Progress in Photovoltaic Research and Applications;16:1730.(72)

[6] Srinivas, K. S. (1992). "Energy Investments and Production Costs of Amorphous Silicon PV Modules", Report for the Swiss Federal Department of Energy, Universite de Neuchatel.(73)

[7] Schaefer, H. Hagedorn, G.. (1992). "Hidden energy and correlated environmental characteristics of P.V. power generation". Renewable energy;2(2):159-66. (37)

[8] Reddy, B.V. Jagadish, K.S. (2003). "Embodied energy of common and alternative building materials and technologies", Energy and Buildings; 35(2):129-137. (75)

[9] Shukla, A. Tiwari, G.N. Sodha, M.S. (2009). "Embodied energy analysis of adobe house", Renewable Energy; 34(3):755-761.(76)

[10] GEMIS, (2002), Global emission model for integrated systems, GEMIS 4.1 Database (September 2002), OkoInstitute Darmstadt, Germany.(77)

[11] Sherwani, A.F. Usmani, J.A. Varun, Siddhartha. (2011). "Life cycle assessment of $50 \mathrm{~kW}_{\mathrm{p}}$ grid connected solar photovoltaic system in India", International Journal of Energy and Environment; 2(1):49-56(78) 